\section{(A) Check for updates}

Cite this: Food Funct., 2019, 10, 1340

\title{
Chemical composition and bioactive properties of Sanguisorba minor Scop. under Mediterranean growing conditions $\uparrow$
}

\author{
Anestis C. Karkanis, ${ }^{a}$ Ângela Fernandes, ${ }^{\mathrm{b}}$ Josiana Vaz, (D) ${ }^{\mathrm{b}}$ \\ Spyridon Petropoulos, (D) *a Eleftheria Georgiou, ${ }^{a}$ Ana Ciric, (D) ${ }^{c}$ Marina Sokovic, (D) \\ Taofiq Oludemi, ${ }^{\mathrm{b}}$ Lillian Barros (D) $^{\mathrm{b}}$ and Isabel C. F. R. Ferreira (D)*b
}

\begin{abstract}
Sanguisorba minor Scop. is a perennial plant native to the Mediterranean region which exhibits several medicinal activities. In the present study, plant growth, chemical composition, and antitumor and antimicrobial properties of $S$. minor plants were evaluated under different growing conditions. In particular, plants were grown on different substrates, namely (A) peat, (B) peat: perlite $(1: 1)$ and (C) peat: perlite $(2: 1)$. The dry weight of the aerial parts and roots was higher for the peat treatment (A), whereas plant growth was severely affected in the peat: perlite $(1: 1)$ treatment (B). The major detected sugars were fructose and glucose, while the peat:perlite $(2: 1)$ treatment resulted in a significant increase of $\alpha$-tocopherol, glucose and total sugars content, especially in the aerial parts. Oxalic acid and citric acid were the major organic acids detected, with a varied effect of growth substrate on organic acid profile. Growth substrate and plant part also had a significant effect on fatty acid composition, especially on linoleic acid and $\alpha$-linolenic acid content which was higher in the peat : perlite $(1: 1)$ treatment in both aerial parts and roots. An impact on the composition of phenolic compounds was also observed, where the plants grown on peat : perlite $(2: 1)$ and peat : perlite $(1: 1)$ substrates had the highest content of individual and total phenolic compounds in their aerial parts and roots, respectively. Moreover, roots contained significantly higher amounts of phenolic compounds than the aerial parts. Moreover, plant extracts exhibited antiproliferative activity against four tumor cell lines (HeLa, HepG2, MCF-7 and NCl-H460) and a primary culture of porcine liver cells (PLP2), as well as significant antimicrobial properties. In conclusion, S. minor presented significant bioactive properties, while growth substrates affected the nutritional value, chemical composition, antitumor and antimicrobial properties of the species which could be probably attributed to the higher phenolic compound content and different compositions of phenolic compounds. Therefore, although the species is commonly found in the Mediterranean region, it is underexploited yet and its plant tissues could be a potential source of natural bioactive compounds with further use in pharmaceutical and medicinal applications.
\end{abstract}

Received 29th December 2018, Accepted 30th January 2019

DOI: $10.1039 / \mathrm{c} 8 \mathrm{fo} 02601 \mathrm{~g}$

rsc.li/food-function

\section{Introduction}

Sanguisorba minor L. (small or little burnet) is a multiannual plant 60-105 cm tall, and is a member of the Rosaceae family. ${ }^{1}$

\footnotetext{
${ }^{a}$ Department of Agriculture Crop Production and Rural Environment, University of Thessaly, Fytokou St., 38446 Volos, Greece. E-mail: spetropoulos@uth.gr; Fax: +30-2421093155; Tel: +30-2421093196

${ }^{b}$ Centro de Investigação de Montanha (CIMO), Instituto Politécnico de Bragança, Campus de Santa Apolónia, 5300-253 Bragança, Portugal. E-mail: iferreira@ipb.pt; Fax: +351-273325405; Tel: +351-273303219

${ }^{c}$ University of Belgrade, Department of Plant Physiology, Institute for Biological Research "Siniša Stanković", Bulevar Despota Stefana 142, 11000 Belgrade, Serbia $\dagger$ Electronic supplementary information (ESI) available. See DOI: 10.1039/ c8fo02601g
}

The species is widely distributed throughout Europe and is commonly found in dry and semi-dry grasslands of the Mediterranean basin. ${ }^{2,3} S$. minor and other species of this genus (e.g. S. officinalis) are commonly used as medicinal species, while they are also edible and their young shoots and leaves are usually used in mixed vegetable salads. ${ }^{2,4,5}$ Plants grown in the wild are also used as forage species due to their high nutritional value, dry matter digestibility and metabolizable energy. ${ }^{6}$

Sanguisorba species are rich sources of secondary metabolites with significant bioactive properties. According to Zhao et al., ${ }^{7}$ more than 120 compounds belonging to various chemical classes (flavonoids, phenols and triterpenoids) have been detected in the aboveground parts and roots of $S$. minor and 
S. officinalis. In particular, phenolic compounds are of major importance for the bioactive properties of these species, and several studies have described their phenolic content and composition of both aerial parts and roots. ${ }^{8-10}$ The various detected compounds have been correlated with several bioactive properties, such as medicinal and therapeutic properties, and have been commonly used in traditional medicine for the treatment of hemostasis, leukopenia, haemorrhaging, burns and inflammation. ${ }^{7}$ Moreover, Ferreira et al. ${ }^{11}$ reported that ethanolic extracts from aerial parts of $S$. minor showed a significant inhibitory activity against the acetylcholinesterase (AChE) enzyme and high antioxidant activity. Other beneficial effects to humans include the in vitro suppression of cancer cell migration through plasmin-mediated mechanisms, which according to Cuccioloni et al. ${ }^{12}$ is due to the activity of ethanolic extracts and the high content of quercetin-3-glucuronide in S. minor. Moreover, other compounds such as ziyuglycoside I and II which are isolated from $S$. officinalis roots have been associated with apoptosis of human gastric carcinoma cells (BGC-823) and human retinoblastoma (RB WERI-Rb-1) cells. ${ }^{13,14}$ Recently, it has been reported that the activity of $S$. officinalis extracts against colorectal cancer cells may be due to its blocking activity against the signaling pathway of $\mathrm{Wnt} / \beta$-catenin and the activation of the mitochondria-caspase-dependent apoptotic pathway. ${ }^{15,16}$ Other therapeutic effects of Sanguisorba species and their active constituents include anti-allergic, anti-inflammatory, antiangiogenic, antiviral, antibacterial, antiobesity, hemostatic and neuroprotective properties. ${ }^{7,17,18}$

Considering the significant medicinal properties of Sanguisorba species, commercial cultivation of small burnet has great potential and it could be significant for its further use. So far, most of the studies report on S. officinalis, while reports regarding $S$. minor refer mostly to handpicked plants grown in the wild, without further details regarding the growing conditions. The present study aimed to examine the growth of $S$. minor plants on different commercial substrates in order to propose their commercial cultivation as an alternative horticultural species. Additionally, the impact of growth substrates on proximate composition, chemical composition, and bioactivities of the plant tissues was assayed in order to highlight the important role of $S$. minor in human diet and health.

\section{Materials and methods}

\subsection{Plant material and experimental layout}

Small burnet (Sanguisorba minor Scop.) seeds were gathered from wild plants located in Central Greece (Domokos region) in the middle of June 2015. The experiment was conducted at the experimental field of the University of Thessaly in Velestino, Greece (22.756E, 39.396N). Sowing of seeds was carried out directly in $2 \mathrm{~L}$ pots on December 4, 2015, and after emergence, the number of seedlings was reduced to five plants in each pot two weeks after germination and plant establishment.
An experiment with a completely randomized design layout was carried out with fifteen replicates (pots) per treatment $(n=15)$. The substrate treatments were as follows: (A) peat, (B) peat : perlite $(1: 1 \mathrm{v} / \mathrm{v})$ and $(C)$ peat : perlite $(2: 1 \mathrm{v} / \mathrm{v})$. Regarding fertilization, all treatments were fertilized with the same amount of nitrogen $\left(34.5 \mathrm{~kg} \mathrm{ha}{ }^{-1}\right.$ ), namely $50 \mathrm{~kg} \mathrm{ha}{ }^{-1}$ of ammonium nitrate (34.5-0-0) at 40 and 70 days after sowing (DAS). Irrigation was applied when the plants of treatment A showed the first symptoms of wilt, via a sprinkler irrigation system and depending on rain incidence. Meteorological data of the experimental site are presented in ESI Fig. S1A. $\dagger$

\subsection{Measurements}

2.2.1 Small burnet growth. To determine the effects of the studied substrates on plant growth, dry weight of the aerial parts and roots was recorded throughout the growing period (at 89, 109, 123, and 173 DAS) with three measurements per pot. Dry weight of plants was recorded after drying the samples at $70{ }^{\circ} \mathrm{C}$ for $72 \mathrm{~h}$. For root biomass evaluation, roots were put in saline water in order to remove the substrate particles, then dried with absorbing paper and finally weighed for fresh weight determination. For root dry weight evaluation, samples were dried at $70{ }^{\circ} \mathrm{C}$ for $72 \mathrm{~h}$. The relative chlorophyll content (SPAD index values) was also determined non-destructively on fully expanded leaves at 89, 123, and 173 DAS, using a SPAD 502 (Konica Minolta Optics, Osaka, Japan), with three measurements per pot $(n=5)$.

For chemical composition analyses, plants were collected in May 2016 (173 DAS). After harvest, plants were separated into aerial parts and roots, while roots were further cleaned for substrate particle removal as described above. Fresh samples of plant tissues were stored at $-80{ }^{\circ} \mathrm{C}$ and then lyophilized. Lyophilized samples were ground to powder with a pestle and mortar, put in plastic and air-sealed bags and stored at $-80{ }^{\circ} \mathrm{C}$ until analysis.

2.2.2 Sample and extract preparation. One gram of sample was macerated, with agitation $(150 \mathrm{rpm})$ and $30 \mathrm{~mL}$ of methanol/water $(80: 20, \mathrm{v} / \mathrm{v})$ for $1 \mathrm{~h}$, at room temperature and filtered through a Whatman No. 4 paper. Afterwards, the samples were re-extracted with an additional portion of the mentioned solution, the extracts were evaporated in a rotary evaporator (Büchi R-210, Flawil, Switzerland), and the aqueous phase was frozen and lyophilized (FreeZone 4.5 model 7750031, Labconco, Kansas City, MO, USA).

2.2.3 Chemical composition analysis. Proximate analyses. Samples were analyzed in terms of macronutrients (moisture, proteins, fat, carbohydrates and ash), according to the AOAC procedures. ${ }^{19}$ The crude protein $(\mathrm{N} \times 6.25)$ was determined by the Kjeldahl method (991.02); the ash content (935.42) was estimated by subjecting the sample to incineration at $600 \pm$ $15^{\circ} \mathrm{C}$ for $5 \mathrm{~h}$; the crude fat was determined using a Soxhlet apparatus with petroleum ether (989.05); and the total carbohydrate content was estimated by difference. The total energy was calculated using the following equation: energy (kcal) = $4 \times(\mathrm{g}$ protein $+\mathrm{g}$ carbohydrates $)+9 \times(\mathrm{g}$ fat $)$. 
Tocopherols. For tocopherol determination, a previously described protocol was followed, ${ }^{20}$ using a HPLC system (Knauer, Smartline system 1000, Berlin, Germany) coupled to a fluorescence detector (FP-2020; Jasco, Easton, USA) programmed for excitation at $290 \mathrm{~nm}$ and emission at $330 \mathrm{~nm}$. Quantification was carried out based on calibration curves obtained from commercial standards, using the internal standard method. The results were recorded and processed using Clarity 2.4 software (DataApex, Prague, Czech Republic).

Free sugars. The sugar molecules were determined following a procedure previously described. ${ }^{20}$ Determination of free sugars was carried using the internal standard (IS, melezitose, Sigma-Aldrich, St Louis, MO, USA) method and analysed by high performance liquid chromatography coupled to a refraction index detector (HPLC-RI, Knauer, Smartline system 1000). The results were recorded and processed using Clarity 2.4 software (DataApex, Prague, Czech Republic).

Organic acids. Identification and quantification of organic acids were carried out according to the conditions described by Barros et al., ${ }^{21}$ determined by ultra-fast liquid chromatography (Shimadzu 20A series UFLC, Shimadzu Corporation, Kyoto, Japan) coupled to a diode-array detector (DAD), using 215 and $245 \mathrm{~nm}$ as the preference wavelengths. The results were recorded and processed using LabSolutions Multi LC-PDA software (Shimadzu Corporation, Kyoto, Japan).

Fatty acids. Identification of fatty acids was carried out following the method described by Barros et al. ${ }^{20}$ The fatty acids were determined by gas chromatography coupled with a flame ionization detector (GC-FID/capillary column, DANI model GC 1000, Contone, Switzerland) and a split/splitless injector, using a Macherey-Nagel column. The fatty acids were identified by comparing the relative retention times of FAME peaks from samples with commercial standards. The results were treated using the Chromatography Station for Windows CSW (version 1.7) software from DataApex (Podohradska, Czech Republic) and expressed in relative percentages.

Phenolic compounds. The hydromethanolic extracts were redissolved in methanol/water $(80: 20 \mathrm{v} / \mathrm{v})$ to a final concentration of $10 \mathrm{mg} \mathrm{mL}^{-1}$ for phenolic compound identification and quantification, which was performed in LC-DAD-ESI/MSn analyses (Dionex Ultimate 3000 UHPLC instrument, Thermo Scientific, San Jose, CA, USA) equipped with a diode-array detector (280, 330 and $370 \mathrm{~nm}$ ) and coupled to a mass detector (operated in the negative mode), following a procedure previously reported by Bessada et al. ${ }^{22}$ For quantitative analysis, a calibration curve $\left(200-5 \mu \mathrm{g} \mathrm{mL}^{-1}\right)$ for each available phenolic standard was constructed based on the UV signal: ellagic acid $\left(y=26719 x-317255, R^{2}=0.999\right)$, catechin $(y=84950 x-$ $\left.23200, R^{2}=0.99\right)$, gallic acid $\left(y=131538 x+292163, R^{2}=\right.$ 0.999), apigenin-7-O-glucoside $\left(y=10683 x-45794, R^{2}=\right.$ 0.996), quercetin-3-O-glucoside $\left(y=34843 x-160173, R^{2}=\right.$ 0.999). The results were expressed as milligrams per gram of the extract.

2.2.4 Cytotoxicity activity. Cytotoxicity was evaluated using four tumor cell lines, HeLa (cervical carcinoma), HepG2 (hepatocellular carcinoma), MCF-7 (breast adenocarcinoma) and NCI-H460 (non-small cell lung cancer), using the sulforhodamine B assay following a previously described methodology. ${ }^{23}$ Freshly harvested porcine liver was used to obtain non-tumor cells denoted as PLP2. Results were expressed in $\mathrm{GI}_{50}$ values, which correspond to the extract concentration that inhibited $50 \%$ net cell growth. Ellipticine was used as the positive control.

2.2.5 Antimicrobial activity. Three Gram-positive bacteria: Bacillus cereus (food isolate), Staphylococcus aureus (ATCC 6538) and Listeria monocytogenes (NCTC 7973), three Gramnegative bacteria: Escherichia coli (ATCC 35210), Enterobacter cloacae (human isolate) and Salmonella typhimurium (ATCC 13311), and six fungi: Aspergillus fumigatus (ATCC 1022), Aspergillus ochraceus (ATCC 12066), Aspergillus niger (ATCC 6275), Penicillium ochrochloron (ATCC 9112), Penicillium funiculosum (ATCC 36839) and Penicillium verrucosum var. cyclopium (food isolate), were used in this study. Antimicrobial assay was carried out by the microdilution method as previously described by Petropoulos et al. $^{24}$ The concentrations that completely inhibited the bacterial growth (MICs) were determined by a colorimetric microbial viability assay, and minimal bactericidal concentration (MBC) and minimal fungicidal concentration (MFC) were also calculated. Streptomycin, ampicillin, ketoconazole, and bifonazole (Sigma-Aldrich, St Louis, MO, USA) were used as positive controls, and 5\% DMSO was used as the negative control.

\subsection{Statistical analysis}

The experimental layout was arranged according to the completely randomized design. Statistical analysis of the results was carried out with SigmaPlot 12 software (Systat Software, San Jose, CA, USA) by applying one-way ANOVA, followed by the Tukey's HSD test $(p<0.05)$. Regarding the chemical composition and bioactive properties, three samples were analysed for each treatment and all the assays were carried out in triplicate. Data were expressed as mean \pm standard deviation.

\section{Results and discussion}

\subsection{Plant growth}

Growth media had a significant impact on growth of $S$. minor plants (ESI Fig. S1B $\dagger$ ). In particular, dry weight of aerial parts was higher for the plants grown on the peat substrate, while the lowest dry weight was recorded when a mixture of peat and perlite was used $(1: 1 \mathrm{v} / \mathrm{v})$. Moreover, the lowest values of roots' dry weight were recorded for the peat: perlite $(1: 1 \mathrm{v} / \mathrm{v})$ treatment (ESI Fig. S1C $\dagger$ ). At early growth stages, plants were characterized by low growth rates probably due to low temperatures during this period (ESI Fig. S1A $\dagger$ ). Our results revealed that the growing conditions during the period of April to May were more favourable for the peat treatment in comparison to the other substrate treatments, probably due to the better water retention properties and the alleviation of high-temperature-induced stress conditions for plants. Similarly, BaghbaniArani et $a l{ }^{25}$ and Mohammadi et $a .^{26}$ reported that water 
stress affects the growth of medicinal plants such as fenugreek (Trigonella foenum-graecum L.) and chamomile (Matricaria chamomilla L.).

\subsection{Chlorophyll content}

Concerning the relative chlorophyll content (SPAD index values), there were significant differences between treatments, as shown in ESI Fig. S1D. $\dagger$ Throughout the growing period, the lowest values were found in the peat: perlite $(1: 1 \mathrm{v} / \mathrm{v})$ treatment, probably due to the rapid removal of water from the growth substrate in comparison to other treatments which contained smaller amounts of peat. Also, Baghbani et al. ${ }^{25}$ reported that the chlorophyll content of fenugreek decreased under water stress conditions. To the best of our knowledge, chlorophyll content in leaves of $S$. minor has not been described in the literature so far. Similar SPAD index values have been reported by Karkanis and Petropoulos ${ }^{27}$ in common purslane (Portulaca oleracea L.) grown under the same conditions as reported in the present study.

\subsection{Chemical composition}

Regarding fat, protein, ash and carbohydrate contents of the aerial parts and roots, significant variation was observed among the studied treatments (Table 1). The lowest contents of proteins and ash in roots and aerial parts of $S$. minor plants were recorded in the peat:perlite $(2: 1 \mathrm{v} / \mathrm{v})$ treatment, whereas fat content was the lowest in the peat:perlite $(2: 1 \mathrm{v} / \mathrm{v})$ and peat: perlite $(1: 1 \mathrm{v} / \mathrm{v})$ treatments for aerial parts and roots, respectively. In contrast, the highest content of carbohydrates was recorded in the same treatment (peat : perlite $(2: 1 \mathrm{v} / \mathrm{v}))$. Concerning the energetic value of aerial parts and roots, the highest values were recorded in the peat : perlite $(1: 1 \mathrm{v} / \mathrm{v})$ treatment.

Composition of sugars and tocopherols is presented in Table 2. The major identified sugars in aerial parts and roots

Table 1 Nutritional value ( $\mathrm{g}$ per $100 \mathrm{~g} \mathrm{dw}$ ) and energetic value (kcal per $100 \mathrm{~g} \mathrm{dw}$ ) of Sanguisorba minor leaves + stems and roots in relation to the substrate type (mean \pm SD)

\begin{tabular}{|c|c|c|c|c|c|}
\hline Substrate type & Fat & Proteins & Ash & Carbohydrates & Energy \\
\hline Peat & $2.63 \pm 0.03 a$ & $12 \pm 1.0 \mathrm{a}$ & $4.8 \pm 0.2 \mathrm{a}$ & $80.6 \pm 0.1 b$ & $449.5 \pm 3.1 \mathrm{a}$ \\
\hline \multicolumn{6}{|l|}{ Roots } \\
\hline Peat & $3.10 \pm 0.15 a$ & $11.83 \pm 0.07 \mathrm{a}$ & $4.8 \pm 0.2 \mathrm{a}$ & $80.24 \pm 0.09 c$ & $446.7 \pm 2.2 b$ \\
\hline
\end{tabular}

Small Latin letters in the same column indicate significant differences between means of the same plant part (leaves + stems, and roots) according to the Tukey's HSD test $(P<0.05)$.

Table 2 Composition of $\alpha$-tocopherol, sugar and organic acids (mg per $100 \mathrm{~g} \mathrm{dw}$ ) in Sanguisorba minor leaves + stems and roots in relation to the substrate type (mean \pm SD)

\begin{tabular}{|c|c|c|c|c|}
\hline Substrate type & $\alpha$-Tocopherol & Fructose & Glucose & Total sugars \\
\hline \multicolumn{5}{|l|}{ Leaves + stems } \\
\hline Peat & $4.42 \pm 0.07 \mathrm{~b}$ & $2.70 \pm 0.01 \mathrm{a}$ & $3.39 \pm 0.06 c$ & $6.1 \pm 0.1 b$ \\
\hline Peat: perlite $(1: 1 \mathrm{v} / \mathrm{v})$ & $4.40 \pm 0.03 b$ & $2.67 \pm 0.07 a$ & $3.6 \pm 0.2 b$ & $6.3 \pm 0.3 \mathrm{~b}$ \\
\hline Peat: perlite $(2: 1 \mathrm{v} / \mathrm{v})$ & $5.8 \pm 0.1 \mathrm{a}$ & $2.9 \pm 0.3 \mathrm{a}$ & $4.3 \pm 0.1 \mathrm{a}$ & $7.3 \pm 0.5 \mathrm{a}$ \\
\hline \multicolumn{5}{|l|}{ Roots } \\
\hline Peat & $0.66 \pm 0.07 \mathrm{c}$ & $0.92 \pm 0.04 a$ & $1.94 \pm 0.07 \mathrm{~b}$ & $2.9 \pm 0.1 \mathrm{~b}$ \\
\hline Peat : perlite $(1: 1 \mathrm{v} / \mathrm{v})$ & $1.02 \pm 0.06 \mathrm{~b}$ & $0.81 \pm 0.06 b$ & $2.33 \pm 0.05 \mathrm{a}$ & $3.13 \pm 0.01 \mathrm{a}$ \\
\hline Peat: perlite $(2: 1 \mathrm{v} / \mathrm{v})$ & $1.25 \pm 0.11 \mathrm{a}$ & $0.82 \pm 0.01 b$ & $2.3 \pm 0.1 \mathrm{a}$ & $3.12 \pm 0.02 \mathrm{a}$ \\
\hline Substrate type & Oxalic acid & Citric acid & Fumaric acid & Total organic acids \\
\hline \multicolumn{5}{|l|}{ Leaves + stems } \\
\hline Peat & $0.34 \pm 0.02 b$ & $1.12 \pm 0.05 a$ & $\operatorname{tr}$ & $1.46 \pm 0.06 \mathrm{a}$ \\
\hline Peat: perlite $(1: 1 \mathrm{v} / \mathrm{v})$ & $0.46 \pm 0.01 \mathrm{a}$ & $0.93 \pm 0.01 b$ & $\operatorname{tr}$ & $1.39 \pm 0.01 b$ \\
\hline Peat: perlite $(2: 1 \mathrm{v} / \mathrm{v})$ & $0.35 \pm 0.02 b$ & $0.88 \pm 0.02 b$ & $\operatorname{tr}$ & $1.24 \pm 0.02 \mathrm{c}$ \\
\hline \multicolumn{5}{|l|}{ Roots } \\
\hline Peat & $0.54 \pm 0.03 c$ & $4.22 \pm 0.08 \mathrm{~b}$ & $\operatorname{tr}$ & $4.77 \pm 0.08 c$ \\
\hline Peat : perlite $(1: 1 \mathrm{v} / \mathrm{v})$ & $1.21 \pm 0.02 \mathrm{a}$ & $3.71 \pm 0.04 \mathrm{c}$ & $\operatorname{tr}$ & $4.92 \pm 0.04 \mathrm{~b}$ \\
\hline Peat: perlite $(2: 1 \mathrm{v} / \mathrm{v})$ & $0.71 \pm 0.03 b$ & $4.6 \pm 0.1 \mathrm{a}$ & $\operatorname{tr}$ & $5.3 \pm 0.1 \mathrm{a}$ \\
\hline
\end{tabular}

tr: traces. Small Latin letters in the same column indicate significant differences between means of the same plant part (leaves + stems, and roots) according to the Tukey's HSD test $(P<0.05)$. 
were fructose and glucose, while regarding tocopherols, only the $\alpha$-tocopherol isoform was detected. Substrate composition significantly affected the individual and total sugar contents, and $\alpha$-tocopherol content in both aerial parts and roots of $S$. minor plants, and aerial parts of the plants grown in the peat: perlite $(2: 1 \mathrm{v} / \mathrm{v})$ treatment had the highest amounts of these compounds. Moreover, the lowest values of $\alpha$-tocopherol, glucose and total sugars were recorded in the peat treatment, while the content of sugars and a-tocopherol was higher in the aerial parts of plants in comparison to the roots. Similarly, Zhang et $a .^{28}$ reported that fructose and glucose were the major detected sugars in the roots of S. officinalis, although they detected other compounds such as rhamnose, arabinose, xylose and galactose in different fractions of polysaccharide extracts. Regarding the organic acid composition, oxalic acid and citric acid were the principal detected organic acids, whereas only traces of fumaric acid were observed (Table 2). Moreover, organic acid content was higher in the roots than in the aerial parts of the plants for all the substrate treatments.
Fatty acid composition is presented in Table 3 . The results showed significant differences in fatty acid composition between the aerial plant parts and roots. In particular, the aerial plant parts were abundant in $\alpha$-linolenic acid $(49.4 \%-$ $52.4 \%)$, followed by palmitic $(14.6 \%-15.6 \%)$ and linoleic acid (12.9\%-13.1\%), while stearic, tricosylic, lauric and eicosatrienoic acids were also found in smaller amounts. In contrast, roots contained high amounts of linoleic $(20.7 \%-23.8 \%)$ and tricosylic acids $(20.5 \%-24.1 \%)$, followed by $\alpha$-linolenic $(12.8 \%-$ $15.4 \%)$ and palmitic acids (11.9\%-13.1\%), while stearic, oleic, dihomo- $\gamma$-linolenic and behenic acids were found in smaller amounts. To the best of our knowledge, this is the first report where the fatty acid composition of $S$. minor roots is described.

Similar to our study, Elgersma et al. ${ }^{29}$ suggested that $\alpha$-linolenic acid was the main fatty acid (46.96\%) in S. minor forage, while linoleic and palmitic acids were found in smaller amounts (21.24\% and $15.83 \%$, respectively). In contrast, Viano et $a l .{ }^{30}$ who studied the nutritional value of $S$. minor spp. muricata also detected palmitic, linoleic and $\alpha$-linolenic

Table 3 Fatty acid composition (\%) of the studied Sanguisorba minor samples (mean \pm SD) from leaves + stems and roots in relation to the substrate type

\begin{tabular}{|c|c|c|c|c|c|c|}
\hline & \multicolumn{3}{|l|}{ Leaves + stems } & \multicolumn{3}{|l|}{ Roots } \\
\hline & Peat & $\begin{array}{l}\text { Peat: perlite } \\
(1: 1 \mathrm{v} / \mathrm{v})\end{array}$ & $\begin{array}{l}\text { Peat: perlite } \\
(2: 1 \mathrm{v} / \mathrm{v})\end{array}$ & Peat & $\begin{array}{l}\text { Peat: perlite } \\
(1: 1 \mathrm{v} / \mathrm{v})\end{array}$ & $\begin{array}{l}\text { Peat: perlite } \\
(2: 1 \mathrm{v} / \mathrm{v})\end{array}$ \\
\hline C8:0 & $0.058 \pm 0.002 b$ & $0.068 \pm 0.001 \mathrm{a}$ & $0.051 \pm 0.001 \mathrm{c}$ & $0.101 \pm 0.001 \mathrm{a}$ & $0.078 \pm 0.001 c$ & $0.088 \pm 0.001 b$ \\
\hline C10:0 & $0.24 \pm 0.01 \mathrm{a}$ & $0.180 \pm 0.004 \mathrm{c}$ & $0.20 \pm 0.02 b$ & $0.19 \pm 0.01 b$ & $0.151 \pm 0.004 c$ & $0.86 \pm 0.01 \mathrm{a}$ \\
\hline C11:0 & $0.59 \pm 0.02 b$ & $0.62 \pm 0.04 \mathrm{~b}$ & $0.765 \pm 0.003 \mathrm{a}$ & $1.22 \pm 0.08 \mathrm{c}$ & $1.48 \pm 0.08 \mathrm{~b}$ & $2.17 \pm 0.06 \mathrm{a}$ \\
\hline C12:0 & $2.12 \pm 0.06 \mathrm{a}$ & $1.88 \pm 0.01 b$ & $1.94 \pm 0.05 b$ & $1.77 \pm 0.05 \mathrm{a}$ & $1.64 \pm 0.07 \mathrm{~b}$ & $1.35 \pm 0.07 c$ \\
\hline C16:0 & $15.61 \pm 0.08 \mathrm{a}$ & $15.2 \pm 0.2 b$ & $14.6 \pm 0.1 \mathrm{c}$ & $11.9 \pm 0.3 b$ & $12.9 \pm 0.1 \mathrm{a}$ & $13.13 \pm 0.03 a$ \\
\hline C16:1 & $1.46 \pm 0.01 \mathrm{a}$ & $1.01 \pm 0.01 b$ & $0.888 \pm 0.009 c$ & $0.36 \pm 0.03 b$ & $0.174 \pm 0.006 c$ & $0.59 \pm 0.02 \mathrm{a}$ \\
\hline C17:0 & $0.601 \pm 0.009 a$ & $0.570 \pm 0.005 b$ & $0.566 \pm 0.006 b$ & $0.63 \pm 0.01 b$ & $0.735 \pm 0.006 \mathrm{a}$ & $0.72 \pm 0.04 \mathrm{a}$ \\
\hline C18:0 & $3.49 \pm 0.03 b$ & $3.53 \pm 0.01 \mathrm{a}$ & $3.39 \pm 0.01 c$ & $4.77 \pm 0.04 c$ & $5.19 \pm 0.07 \mathrm{~b}$ & $5.53 \pm 0.02 \mathrm{a}$ \\
\hline C18:1n9c & $0.962 \pm 0.001 b$ & $0.974 \pm 0.006 \mathrm{a}$ & $0.943 \pm 0.004 \mathrm{c}$ & $1.96 \pm 0.01 \mathrm{c}$ & $2.6 \pm 0.1 \mathrm{a}$ & $2.15 \pm 0.01 b$ \\
\hline $\mathrm{C} 18: 2 \mathrm{n} 6 \mathrm{c}$ & $12.91 \pm 0.02 \mathrm{~b}$ & $13.12 \pm 0.01 \mathrm{a}$ & $12.89 \pm 0.01 b$ & $20.7 \pm 0.2 c$ & $23.82 \pm 0.03 a$ & $23.29 \pm 0.03 b$ \\
\hline C18:3n6 & $0.146 \pm 0.008 b$ & $0.107 \pm 0.004 c$ & $0.161 \pm 0.004 \mathrm{a}$ & $1.10 \pm 0.03 b$ & $1.06 \pm 0.09 \mathrm{~b}$ & $1.76 \pm 0.03 a$ \\
\hline C20:3n3 & $1.35 \pm 0.06 \mathrm{~b}$ & $1.41 \pm 0.01 \mathrm{a}$ & $1.26 \pm 0.03 c$ & $0.488 \pm 0.001 \mathrm{a}$ & $0.310 \pm 0.001 \mathrm{c}$ & $0.44 \pm 0.02 \mathrm{~b}$ \\
\hline $\mathrm{C} 22: 0$ & $0.794 \pm 0.001 b$ & $0.88 \pm 0.01 \mathrm{a}$ & $0.89 \pm 0.07 a$ & $9.3 \pm 0.5 \mathrm{a}$ & $6.02 \pm 0.04 \mathrm{~b}$ & $5.7 \pm 0.2 \mathrm{~b}$ \\
\hline C22:1 & $0.130 \pm 0.003 a$ & $0.137 \pm 0.006 a$ & $0.080 \pm 0.004 \mathrm{~b}$ & $0.128 \pm 0.001 b$ & $0.208 \pm 0.002 \mathrm{a}$ & $0.21 \pm 0.01 \mathrm{a}$ \\
\hline $\mathrm{C} 20: 5 \mathrm{n} 3$ & $0.119 \pm 0.007 \mathrm{c}$ & $0.185 \pm 0.004 b$ & $0.23 \pm 0.01 \mathrm{a}$ & $0.081 \pm 0.007 \mathrm{c}$ & $0.24 \pm 0.01 \mathrm{a}$ & $0.139 \pm 0.008 \mathrm{~b}$ \\
\hline $\mathrm{C} 22: 2$ & $1.2 \pm 0.1 \mathrm{a}$ & $1.05 \pm 0.02 \mathrm{~b}$ & $0.823 \pm 0.004 \mathrm{c}$ & $2.27 \pm 0.01 \mathrm{a}$ & $1.41 \pm 0.07 \mathrm{~b}$ & $1.5 \pm 0.1 b$ \\
\hline C23:0 & $2.6 \pm 0.2 \mathrm{~b}$ & $2.74 \pm 0.21 b$ & $6.07 \pm 0.01 \mathrm{a}$ & $24.1 \pm 0.4 \mathrm{a}$ & $20.5 \pm 0.7 \mathrm{~b}$ & $20.8 \pm 0.1 b$ \\
\hline $\mathrm{C} 24: 1$ & $0.227 \pm 0.006 c$ & $0.24 \pm 0.01 b$ & $1.25 \pm 0.01 \mathrm{a}$ & $0.35 \pm 0.02 \mathrm{a}$ & $0.16 \pm 0.01 b$ & $0.14 \pm 0.01 b$ \\
\hline Total SFA ( $\%$ of total FA) & $29.94 \pm 0.03 b$ & $29.15 \pm 0.03 c$ & $31.91 \pm 0.01 \mathrm{a}$ & $57.9 \pm 0.4 \mathrm{a}$ & $52.8 \pm 0.3 \mathrm{c}$ & $54.1 \pm 0.1 b$ \\
\hline Total MUFA ( $\%$ of total FA) & $2.78 \pm 0.01 b$ & $2.36 \pm 0.01 \mathrm{c}$ & $3.16 \pm 0.01 \mathrm{a}$ & $2.80 \pm 0.02 b$ & $3.2 \pm 0.1 \mathrm{a}$ & $3.09 \pm 0.02 \mathrm{a}$ \\
\hline Total PUFA ( $\%$ of total FA) & $67.28 \pm 0.03 b$ & $68.49 \pm 0.02 \mathrm{a}$ & $64.93 \pm 0.01 c$ & $39.3 \pm 0.4 \mathrm{c}$ & $44.0 \pm 0.2 \mathrm{a}$ & $42.8 \pm 0.1 \mathrm{~b}$ \\
\hline PUFA/SFA & $2.247 \pm 0.002 b$ & $2.349 \pm 0.002 \mathrm{a}$ & $2.035 \pm 0.001 \mathrm{a}$ & $0.680 \pm 0.008 \mathrm{c}$ & $0.834 \pm 0.006 \mathrm{a}$ & $0.791 \pm 0.002 b$ \\
\hline $\mathrm{n} 6 / \mathrm{n} 3$ & $0.271 \pm 0.001 b$ & $0.268 \pm 0.001 b$ & $0.275 \pm 0.001 \mathrm{a}$ & $1.93 \pm 0.006 b$ & $1.767 \pm 0.002 \mathrm{c}$ & $2.036 \pm 0.003 a$ \\
\hline
\end{tabular}

Small Latin letters in the same row indicate significant differences between means of the same plant part (leaves + stems, and roots) according to the Tukey's HSD test $(P<0.05)$. Caprylic acid (C8:0); capric acid (C10:0); undecylic acid (C11:0); lauric acid (C12:0); myristic acid (C14:0); pentadecylic acid (C15:0); palmitic acid (C16:0); palmitoleic acid (C16:1); margaric acid (C17:0); stearic acid (C18:0); oleic acid (C18:1n9); linoleic acid (C18:2n6c); $\gamma$-linolenic acid (C18:3n6); $\alpha$-linolenic acid (C18:3n3); arachidic acid (C20:0); heneicosylic acid (C21:0); dihomo- $\gamma$-linolenic acid (C20:3n6); eicosatrienoic acid (C20:3n3); behenic acid (C22:0); erucic acid (C22:1); eicosapentaeonic acid (C20:5n3); docosadienoic acid (C22:2); tricosylic acid (C23:0); nervonic acid (C24:1); SFA: saturated fatty acids; MUFA: monounsaturated fatty acids; PUFA: polyunsaturated fatty acids; n6/n3: omega-6/omega-3 fatty acids. 
acids as the main fatty acids, although they reported different relative percentages of the abovementioned fatty acids $(29.1 \%$, $22.6 \%$ and $21.4 \%$, respectively). These differences in the literature could be partly attributed to different growing conditions in the abovementioned studies (France and Denmark in particular) and to the harvesting stage. According to Elgersma et al. ${ }^{29}$ cutting dates had a significant effect on individual and total fatty acids, with late harvesting (October) resulting in higher amounts of total fatty acids in various forb species, including $S$. minor.

Polyunsaturated fatty acids (PUFA) was the main class of fatty acids in the case of the aerial parts, whereas saturated fatty acids (SFA) was the prevailing fatty acid class in roots. This resulted in differences in PUFA/SFA ratios between the plant parts, where values in the aerial parts and roots ranged between 2.0 and 2.3 and between 0.68 and 0.83 , respectively. Similarly, the differences in fatty acid composition resulted in different n6/n3 ratios, with aerial parts having lower ratio values than roots ( 0.27 and $1.8-2.0$, respectively). Elgersma et $a .^{29}$ also reported similar values of PUFA/SFA and n6/n3 ratios (2.85 and 0.46 , respectively), although the $n 6 / \mathrm{n} 3$ ratio was higher than that of our study mostly due to the lower content of linoleic acid.

Despite these differences in fatty acid composition, both plant parts showed an exceptional nutritional value, since the PUFA/SFA ratio was lower than 4.0 in both cases, whereas only roots presented the values of the $\mathrm{n} 6 / \mathrm{n} 3$ ratio higher than 0.45 . This result is in contrast to the study of Elgersma et al. ${ }^{29}$ where both PUFA/SFA and n6/n3 ratios were within the indicated range. According to Guil et al. ${ }^{31}$ both of these ratios are essential for the characterization of the fatty acid composition and are associated with beneficial effects for the cardiovascular system. Significant differences were also observed regarding the effect of growth substrates on the fatty acid composition of both plant parts. In particular, the aerial parts of the plants grown on the peat: perlite $(1: 1 \mathrm{v} / \mathrm{v})$ substrate had the highest amounts of $\alpha$-linolenic and linoleic acids, whereas the plants grown on the peat substrate had the highest content of palmitic acid. However, the overall fatty acid composition was better for the plants grown on the peat: perlite $(2: 1 \mathrm{v} / \mathrm{v})$ substrate due to the lowest PUFA/SFA and the highest n6/n3 ratios. Similarly, tricosylic and linoleic acid contents were the highest in the roots of the plants grown on the peat and peat: perlite $(1: 1 \mathrm{v} / \mathrm{v})$ substrates, respectively.

Results regarding the phenolic profile of $S$. minor plant parts detected via HPLC-DAD-ESI/MSn equipment are presented in Table 4. Tentative identification and quantification of phenolic compounds were carried out using the chromatographic characteristics and previous findings regarding the species of Sanguisorba genus. A total of twenty-three individual compounds were detected and classified into three different classes, including phenolic acids, hydrolysable tannins and flavonoids. Thirteen of these compounds were detected in the aerial plant parts, fifteen in the roots and only six compounds in both the plant parts, indicating significant variations in the phenolic compound profile among the studied parts.
Peaks 4 (catechin) and 21 (ellagic acid) were positively identified after comparison with the commercial standards, while both the compounds were previously reported in the ethanolic extract prepared from the roots of Sanguisorba officinalis $^{10}$ and in the methanolic extract prepared from Sanguisorba obtusa, ${ }^{32}$ respectively.

Peaks 1, 5, 7, and 10-14 were identified as hydrolysable tannins, showing UV and MS fragmentation spectra relevant to galloyl and hexahydroxydiphenoyl (HHDP) derivatives. Peak 1 $\left([\mathrm{M}-\mathrm{H}]^{-}\right.$at $\left.m / z 783\right)$ presented a fragmentation pattern which allowed its tentative identification as pedunculagin. ${ }^{33}$ Peak 5 $\left([\mathrm{M}-\mathrm{H}]^{-}\right.$ion at $\left.\mathrm{m} / \mathrm{z} 483\right)$ showed a fragmentation pattern typical to digalloyl glucose, as previously reported. ${ }^{34}$ Peaks 7 and $12\left([\mathrm{M}-\mathrm{H}]^{-}\right.$at $\left.m / z 1567\right)$ were identified as sanguiin $\mathrm{H}-10$ isomers, following the fragmentation pattern previously described by Martins et al. ${ }^{35}$ Peak $10\left([\mathrm{M}-\mathrm{H}]^{-}\right.$at $m / z$ 1251) was tentatively identified as a derivative of punicalagin attached to gallic acid. Peak 11 presented a doubly charged pseudomolecular ion $\left([\mathrm{M}-\mathrm{H}]^{2-}\right.$ at $m / z$ 1401), and its $\mathrm{MS}^{2}$ fragmentation revealed the characteristics which were relevant to trimeric ellagitannin lambertianin C. ${ }^{35}$ Peaks 13 and $14\left([\mathrm{M}-\mathrm{H}]^{-}\right.$ at $\mathrm{m} / \mathrm{z}$ 935) were identified as galloyl-bis-HHDP-glucoside isomers, as previously reported by Martins et al. ${ }^{35}$

Compounds $16\left([\mathrm{M}-\mathrm{H}]^{-}\right.$at $\left.m / z 463\right), 17$ and $18\left([\mathrm{M}-\mathrm{H}]^{-}\right.$ at $m / z 433)$ were identified as ellagic acid derivatives, bearing the loss of a hexosyl moiety $\left([\mathrm{M}-\mathrm{H}-162]^{-}\right)$and pentosyl moiety $\left([\mathrm{M}-\mathrm{H}-132]^{-}\right)$, respectively, and were tentatively matched with ellagic acid hexoside and ellagic acid pentoside, respectively. ${ }^{36}$ The fragmentation pattern and UV-vis characteristics allowed us to tentatively identify these compounds as ellagic acid hexoside and ellagic acid pentoside, respectively. These last compounds were previously described in the methanolic extract prepared from Sanguisorba obtusa. ${ }^{32}$

The remaining compounds correspond to flavonoid derivatives. Peaks $2,3,6$, and 8 presented a UV spectrum $\left(\lambda_{\max }\right.$ 278-282 nm) characteristic of flavan-3-ols. Peaks 2,3 , and 8 presented a pseudomolecular ion and a fragmentation pattern corresponding to the B-type (epi)catechin dimer $\left([\mathrm{M}-\mathrm{H}]^{-}\right.$at $\mathrm{m} / \mathrm{z}$ 577), and peak 6 to the B-type (epi)catechin tetramer $\left([\mathrm{M}-\mathrm{H}]^{-}\right.$at $m / z$ 1153). Compounds $15\left([\mathrm{M}-\mathrm{H}]^{-}\right.$at $\left.m / z 615\right)$, 19 and $20\left([\mathrm{M}-\mathrm{H}]^{-}\right.$at $\left.\mathrm{m} / z 477\right)$, and $22\left([\mathrm{M}-\mathrm{H}]^{-}\right.$at $\left.\mathrm{m} / z 433\right)$ corresponded to quercetin derivatives, presenting a fragmentation pattern corresponding to distinct losses of galloylhexosyl $(-162+152 \mathrm{u})$, glucuronyl $(-176 \mathrm{u})$, and pentosyl $(-132 \mathrm{u})$ moieties, and an elution order relevant to the type of substituent sugars. ${ }^{35}$ Similarly, compounds $23\left([\mathrm{M}-\mathrm{H}]^{-}\right.$at $\left.\mathrm{m} / \mathrm{z} 461\right)$ and $9\left([\mathrm{M}-\mathrm{H}]^{-}\right.$at $\left.m / z 415\right)$ were identified as kaempferol-Oglucuronide and apigenin- $O$-deoxyhexoside, respectively.

The prevailing phenolic compounds in the aerial plant tissues were lambertianin $\mathrm{C}$, sanguiin $\mathrm{H}-10$ isomer 2 and kaempferol-O-glucuronide, followed by $(+)$-catechin and B-type (epi)catechin dimer, whereas in roots, the same phenolic compounds were detected in higher amounts with the exception of kaempferol-O-glucuronide which was not detected (Table 4). The different profile of the phenolic compound composition in rhizomes and leaves has been suggested for $S$. officinalis by 
Table 4 Retention time $\left(R_{\mathrm{t}}\right)$, wavelengths of maximum absorption in the visible region $\left(\lambda_{\max }\right)$, mass spectral data, and tentative identification and quantification of phenolic compounds (mg $\mathrm{g}^{-1}$ extract) in Sanguisorba minor leaves + stems and roots in relation to the substrate type

\begin{tabular}{|c|c|c|c|c|c|c|c|c|c|c|c|}
\hline \multirow[b]{2}{*}{ Compounds } & \multirow[b]{2}{*}{$\begin{array}{l}R_{\mathrm{t}} \\
(\mathrm{min})\end{array}$} & \multirow[b]{2}{*}{$\begin{array}{l}\lambda_{\max } \\
(\mathrm{nm})\end{array}$} & \multirow[b]{2}{*}{$\begin{array}{l}\text { Molecular } \\
\text { ion }[\mathrm{M}-\mathrm{H}]^{-} \\
(\mathrm{m} / \mathrm{z})\end{array}$} & \multirow[b]{2}{*}{$\operatorname{MS}^{2}(m / z)$} & \multirow[b]{2}{*}{$\begin{array}{l}\text { Tentative } \\
\text { identification }\end{array}$} & \multicolumn{3}{|l|}{ Leaves + stems } & \multicolumn{3}{|l|}{ Roots } \\
\hline & & & & & & Peat & $\begin{array}{l}\text { Peat: perlite } \\
(1: 1 \mathrm{v} / \mathrm{v})\end{array}$ & $\begin{array}{l}\text { Peat: perlite } \\
(2: 1 \mathrm{v} / \mathrm{v})\end{array}$ & Peat & $\begin{array}{l}\text { Peat: perlite } \\
(1: 1 \mathrm{v} / \mathrm{v})\end{array}$ & $\begin{array}{l}\text { Peat: perlite } \\
(2: 1 \mathrm{v} / \mathrm{v})\end{array}$ \\
\hline 1 & 5.0 & 276 & 783 & 481(47), 301(100) & Pedunculagin $^{1}$ & nd & nd & nd & $8.0 \pm 0.2 \mathrm{c}$ & $10.59 \pm 0.05 \mathrm{a}$ & $8.7 \pm 0.2 b$ \\
\hline 2 & 5.4 & 280 & 577 & $\begin{array}{l}451(26), 425(100), \\
407(24), 289(12), 287(10)\end{array}$ & $\begin{array}{l}\text { B-type (epi)catechin } \\
\text { dimer }^{2}\end{array}$ & $15.4 \pm 0.3 \mathrm{~b}$ & $17.68 \pm 0.05 \mathrm{a}$ & $17.6 \pm 0.4 \mathrm{a}$ & $37.4 \pm 0.9 \mathrm{~b}$ & $39.4 \pm 0.3 \mathrm{a}$ & $32.1 \pm 0.6 \mathrm{c}$ \\
\hline 3 & 6.2 & 282 & 577 & $\begin{array}{l}451(20), 425(100), \\
407(18), 289(8), 287(8)\end{array}$ & $\begin{array}{l}\text { B-type (epi)catechin } \\
\text { dimer }^{2}\end{array}$ & $16.69 \pm 0.07 c$ & $20.9 \pm 0.1 b$ & $24.4 \pm 0.3 \mathrm{a}$ & $48.8 \pm 0.3 \mathrm{~b}$ & $51.4 \pm 0.3 \mathrm{a}$ & $38.8 \pm 0.4 \mathrm{c}$ \\
\hline 4 & 7.0 & 279 & 289 & $\begin{array}{l}245(100), 205(37) \\
179(21), 125(5)\end{array}$ & $(+)$-Catechin ${ }^{2}$ & $20.4 \pm 0.1 b$ & $17.1 \pm 0.2 \mathrm{c}$ & $20.941 \pm 0.003 a$ & $28.0 \pm 0.5 \mathrm{a}$ & $27.2 \pm 0.8 b$ & $23.7 \pm 0.5 \mathrm{c}$ \\
\hline 5 & 7.4 & 268 & 483 & $313(100), 169(11)$ & Digalloyl-glucoside $^{3}$ & nd & $78.6 \pm 0.8 \mathrm{a}$ & $76 \pm 3 b$ & nd & nd & nd \\
\hline 6 & 7.5 & 278 & 1153 & $\begin{array}{l}865(27), 577(56) \\
289(49)\end{array}$ & $\begin{array}{l}\text { B-type (epi)catechin } \\
\text { tetramer }^{2}\end{array}$ & nd & nd & nd & $26.6 \pm 0.3 \mathrm{~b}$ & $28.0 \pm 0.5 \mathrm{a}$ & $21.3 \pm 0.2 \mathrm{c}$ \\
\hline 7 & 8.5 & 276 & 1567 & $\begin{array}{l}\text { 1265(100), 1103(8), } \\
933(16), 783(5), 633(17) \\
301(72)\end{array}$ & $\begin{array}{l}\text { Sanguiin H-10 } \\
\text { isomer } 1^{1}\end{array}$ & $5.14 \pm 0.02 \mathrm{c}$ & $5.53 \pm 0.03 b$ & $6.3 \pm 0.2 \mathrm{a}$ & $13.0 \pm 0.3 \mathrm{~b}$ & $13.39 \pm 0.03 \mathrm{a}$ & $10.47 \pm 0.03 c$ \\
\hline 8 & 9.1 & 278 & 577 & $\begin{array}{l}451(24), 425(100) \\
407(19), 289(9), 287(13)\end{array}$ & $\begin{array}{l}\text { B-type (epi)catechin } \\
\text { dimer }^{2}\end{array}$ & nd & nd & nd & $26.9 \pm 0.9 b$ & $30.1 \pm 0.2 \mathrm{a}$ & $22.0 \pm 0.2 \mathrm{c}$ \\
\hline 9 & 9.6 & 344 & 415 & $269(100)$ & $\begin{array}{l}\text { Apigenin-O- } \\
\text { deoxyhexoside }^{4}\end{array}$ & $10.54 \pm 0.01 \mathrm{c}$ & $13.66 \pm 0.05 b$ & $16.3 \pm 0.1 \mathrm{~b}$ & nd & nd & nd \\
\hline 10 & 12.0 & 278 & 1251 & $\begin{array}{l}\text { 1083(10), 781(5), 601(5), } \\
301(3)\end{array}$ & Punicalagin gallate $^{1}$ & nd & nd & nd & $21.7 \pm 0.7 \mathrm{a}$ & $19.7 \pm 0.5 b$ & $16.9 \pm 0.2 \mathrm{c}$ \\
\hline 11 & 13.0 & 236 & {$[1401]^{2-}$} & $\begin{array}{l}\text { 1235(10), 933(57), } \\
631(10), 301(5)\end{array}$ & Lambertianin $\mathrm{C}^{1}$ & $22.3 \pm 0.3 \mathrm{~b}$ & $21.7 \pm 0.2 \mathrm{c}$ & $29.65 \pm 0.01 \mathrm{a}$ & $92.9 \pm 0.2 \mathrm{~b}$ & $95.6 \pm 0.4 \mathrm{a}$ & $78.8 \pm 0.6 \mathrm{c}$ \\
\hline 12 & 13.8 & 234 & 1567 & 935(6), 633(71), 301(51) & $\begin{array}{l}\text { Sanguiin H-10 } \\
\text { isomer } 2^{1}\end{array}$ & $22.7 \pm 0.1 c$ & $23.4 \pm 0.2 \mathrm{~b}$ & $25.9 \pm 0.6 \mathrm{a}$ & $64.2 \pm 0.4 \mathrm{~b}$ & $69.8 \pm 0.5 \mathrm{a}$ & $50.4 \pm 0.2 \mathrm{a}$ \\
\hline 13 & 16.0 & 268 & 935 & 633(100), 301(56) & $\begin{array}{l}\text { Galloyl-bis-HHDP- } \\
\text { glucoside }^{1}\end{array}$ & nd & nd & nd & $11.1 \pm 0.2 \mathrm{~b}$ & $11.9 \pm 0.3 \mathrm{a}$ & $10.4 \pm 0.1 \mathrm{c}$ \\
\hline 14 & 16.6 & 268 & 935 & 633(100), 301(72) & $\begin{array}{l}\text { Galloyl-bis-HHDP- } \\
\text { glucoside }{ }^{1}\end{array}$ & nd & nd & nd & $13.13 \pm 0.07 \mathrm{a}$ & $13.1 \pm 0.3 \mathrm{a}$ & $10.78 \pm 0.02 \mathrm{~b}$ \\
\hline 15 & 17.0 & 350 & 615 & 463(100), 301(10) & $\begin{array}{l}\text { Quercetin-galloyl- } \\
\text { hexoside }^{5}\end{array}$ & $1.320 \pm 0.001 \mathrm{a}$ & $1.29 \pm 0.05 a$ & $1.201 \pm 0.002 b$ & nd & nd & nd \\
\hline 16 & 17.3 & 357 & 463 & $301(100)$ & Ellagic acid hexoside $^{1}$ & $3.8 \pm 0.1 \mathrm{c}$ & $4.3 \pm 0.1 \mathrm{~b}$ & $4.439 \pm 0.007 \mathrm{a}$ & nd & nd & nd \\
\hline 17 & 17.4 & 360 & 433 & $301(100)$ & Ellagic acid pentoside ${ }^{1}$ & nd & nd & nd & $8.8 \pm 0.2 b$ & $9.07 \pm 0.05 \mathrm{a}$ & $8.6 \pm 0.1 \mathrm{c}$ \\
\hline 18 & 18.0 & 362 & 433 & $301(100)$ & Ellagic acid pentoside ${ }^{1}$ & nd & nd & nd & $11.66 \pm 0.04 \mathrm{~b}$ & $13.4 \pm 0.1 \mathrm{a}$ & $10.8 \pm 0.2 \mathrm{c}$ \\
\hline 19 & 18.1 & 355 & 477 & $301(100)$ & $\begin{array}{l}\text { Quercetin- } O \text { - } \\
\text { glucuronide }\end{array}$ & $9.31 \pm 0.05 \mathrm{c}$ & $9.47 \pm 0.02 \mathrm{a}$ & $9.39 \pm 0.07 \mathrm{~b}$ & nd & nd & nd \\
\hline 20 & 18.5 & 354 & 477 & $301(100)$ & $\begin{array}{l}\text { Quercetin- } O- \\
\text { glucuronide }^{5}\end{array}$ & $8.49 \pm 0.02 b$ & $1.22 \pm 0.02 \mathrm{c}$ & $10.42 \pm 0.04 \mathrm{a}$ & nd & nd & nd \\
\hline 21 & 19.2 & 363 & 301 & $\begin{array}{l}284(5), 245(10), \\
229(4), 185(11), 173(5), \\
157(3), 145(3)\end{array}$ & Ellagic acid ${ }^{1}$ & nd & nd & nd & $13.3 \pm 0.4 \mathrm{~b}$ & $21.2 \pm 0.4 \mathrm{a}$ & $19.2 \pm 0.1 \mathrm{c}$ \\
\hline 22 & 21.4 & 352 & 433 & $301(100)$ & $\begin{array}{l}\text { Quercetin- } O \text { - } \\
\text { pentoside }^{5}\end{array}$ & $1.521 \pm 0.007 \mathrm{a}$ & $1.22 \pm 0.02 \mathrm{~b}$ & $0.830 \pm 0.002 c$ & nd & nd & nd \\
\hline \multirow[t]{5}{*}{23} & 22.0 & 346 & 461 & 285(100) & $\begin{array}{l}\text { Kaempferol-O- } \\
\text { glucuronide }\end{array}$ & nd & $25.2 \pm 0.3 \mathrm{a}$ & $20.22 \pm 0.03 b$ & nd & nd & nd \\
\hline & & & & & TPA & $3.8 \pm 0.1 \mathrm{c}$ & $4.3 \pm 0.1 \mathrm{~b}$ & $4.44 \pm 0.01 \mathrm{a}$ & $33.7 \pm 0.7 \mathrm{c}$ & $43.7 \pm 0.5 \mathrm{a}$ & $38.5 \pm 0.2 \mathrm{~b}$ \\
\hline & & & & & THT & $50.2 \pm 0.2 \mathrm{c}$ & $129.3 \pm 0.7 \mathrm{~b}$ & $137 \pm 4 a$ & $224 \pm 1 b$ & $234.1 \pm 0.5 \mathrm{a}$ & $186.6 \pm 0.7 \mathrm{c}$ \\
\hline & & & & & $\mathrm{TF}$ & $83.7 \pm 0.2 \mathrm{c}$ & $107.8 \pm 0.7 \mathrm{~b}$ & $121.2 \pm 0.4 \mathrm{a}$ & $168 \pm 1 b$ & $176.07 \pm 0.01 \mathrm{a}$ & $137.85 \pm 0.09 \mathrm{a}$ \\
\hline & & & & & TPC & $137.6 \pm 0.1 \mathrm{c}$ & $241.32 \pm 0.08 b$ & $263 \pm 3 a$ & $426 \pm 3 b$ & $453.8 \pm 0.9 \mathrm{a}$ & $363.0 \pm 0.8 \mathrm{c}$ \\
\hline
\end{tabular}

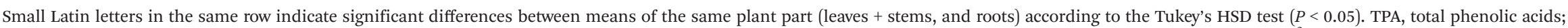

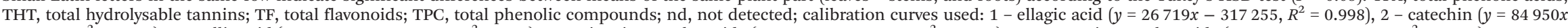
$\left.-23200, R^{2}=0.999\right), 3$ - gallic acid $\left(y=131538 x+292163, R^{2}=0.99\right), 4-$ apigenin-7-O-glucoside $\left(y=10683 x-45794, R^{2}=0.997\right), 5-$ quercetin-3-O-glucoside $\left(y=34843 x-160173, R^{2}=0.999\right)$. 
Biernasiuk et al. ${ }^{9}$ who identified free and bounded phenolic acids (gallic and ellagic acids). According to Gatto et al., ${ }^{37}$ $S$. minor leaves are rich sources of quercetin-3-glucoside and kaempferol-3-glucoside which comprise $52 \%$ of total phenolic compounds, while they also detected apigenin derivatives and chlorogenic, caffeic and chicoric acid derivatives. Moreover, Ayoub $^{8}$ suggested the presence of gallic acid, quercetin, ellagic and kaempferol in ethanolic extracts obtained from S. minor grown in the wild in Egypt. However, although the main aglycones (quercetin-3-O-glucoside and kaempferol-3-O-glucoside) were identified in our study, to the best of our knowledge the rest of the identified phenolic compounds are reported for the first time. Condensed tannins have also been detected in $S$. minor leaves by Kaplan et al., ${ }^{38}$ although they evaluated the total tannin content without performing identification of individual compounds.

Regarding the effects of growth substrates, most of the detected compounds in the aerial parts increased when plants were grown on the peat: perlite $(2: 1 \mathrm{v} / \mathrm{v})$ substrate, whereas the phenolic compound content of the roots increased in the peat : perlite $(1: 1 \mathrm{v} / \mathrm{v})$ treatment. Thus, the total phenolic compound (TPC) content and consequently the individual compound class content in the aerial parts and roots were the highest for plants grown on the peat: perlite $(2: 1 \mathrm{v} / \mathrm{v})$ and peat: perlite $(1: 1 \mathrm{v} / \mathrm{v})$ substrates, respectively. Apart from the phenolic compound composition, plant parts differed in the total phenolic compound and individual compound class contents, with roots being more abundant than the aerial parts and especially regarding phenolic acids where a tenfold increase was recorded. Moreover, the most abundant class of phenolic compounds was that of hydrolysable tannins for both plant parts, except for the case of the aerial parts of peat grown parts where flavonoids were the most abundant class of phenolic compounds.

\subsection{Cytotoxicity activity}

The antiproliferative effects of extracts from plants of $S$. minor were assayed against four cancer cell lines: HeLa, HepG2,
MCF-7 and NCI-H460, and a porcine liver cell primary culture (PLP2). The cytotoxicity of the studied extracts against the cancer cell lines was clearly observed and is presented in Table 5. The extracts from $S$. minor roots showed a higher activity against HeLa $\left(\mathrm{GI}_{50}=60-75 \mu \mathrm{g} \mathrm{mL}{ }^{-1}\right)$, followed by MCF-7 $\left(\mathrm{GI}_{50}=81-199 \mu \mathrm{g} \mathrm{mL}{ }^{-1}\right)$ and NCI-H460 cell lines $\left(\mathrm{GI}_{50}=\right.$ 130-199 $\left.\mu \mathrm{g} \mathrm{mL}^{-1}\right)$. However, the extracts from the roots showed a lower activity against HepG2 cell line compared to the aerial parts, while they were more toxic against the nontumor PLP2 cell line. The highest cytotoxicity against the tested tumor cell lines varied between the studied growth substrates, indicating that the growing conditions may affect the bioactive compound content and the composition of $S$. minor aerial parts and roots. Shin et al. ${ }^{39}$ observed that extracts from plants of $S$. officinalis inhibited the cell growth and induced the death of two oral cancer cell lines (HSC4 and HN22). Liu et $a .^{15}$ suggested that aqueous extracts from the roots of $S$. officinalis exhibited effects synergistic to the 5-fluorouracil inhibiting effects against two colorectal cancer cell lines (HCT-116 and RKO). Moreover, water extracts from the same species ( $S$. officinalis) inhibited the signaling pathway Wnt/ $\beta$-catenin in colorectal cancer cells through down-regulation of $\beta$-catenin and Wnt-targeted genes. ${ }^{16}$

\subsection{Antimicrobial activity}

The antibacterial activity of $S$. minor extracts was tested against strains of six bacteria: Bacillus cereus, Enterobacter cloacae, Escherichia coli, Listeria monocytogenes, Staphylococcus aureus, and Salmonella typhimurium, and the results are presented in Table 6. The MIC and MBC values of extracts varied from 0.075 to $0.45 \mathrm{mg} \mathrm{mL} \mathrm{m}^{-1}$ and 0.15 to $0.60 \mathrm{mg} \mathrm{mL}^{-1}$, respectively. Streptomycin and ampicillin, used as positive controls, presented MIC ranging from 0.04 to 0.20 and 0.25 to $0.75 \mathrm{mg} \mathrm{mL}^{-1}$, respectively. All the plant extracts revealed antibacterial activity, while the extracts from the roots revealed a higher antibacterial capacity in comparison to that from the aerial parts of plants and positive controls, with the only exception

Table 5 Cytotoxicity and antitumor activity of Sanguisorba minor $\left(\mathrm{Gl}_{50}\right.$ values $\left.\mu \mathrm{g} \mathrm{mL}^{-1}\right)$ leaves + stems and roots in relation to the substrate type

\begin{tabular}{|c|c|c|c|c|c|}
\hline Substrate type & $\begin{array}{l}\text { Cytotoxicity to non-tumor } \\
\text { cell lines } \\
\text { PLP2 (porcine liver } \\
\text { primary culture) }\end{array}$ & \multicolumn{4}{|c|}{ Cytotoxicity to tumor cell lines } \\
\hline \multicolumn{6}{|l|}{ Leaves and stems } \\
\hline Peat & $356 \pm 19 a$ & $190 \pm 6 a$ & $177 \pm 9 \mathrm{a}$ & $271 \pm 10 \mathrm{a}$ & $312 \pm 3 a$ \\
\hline Peat : perlite $(1: 1 \mathrm{v} / \mathrm{v})$ & $322 \pm 4 \mathrm{ab}$ & $134 \pm 9 b$ & $178 \pm 8 \mathrm{a}$ & $192 \pm 14 b$ & $303 \pm 7 a$ \\
\hline Peat : perlite $(2: 1 \mathrm{v} / \mathrm{v})$ & $304 \pm 11 b$ & $98 \pm 7 c$ & $67 \pm 5 b$ & $139 \pm 10 c$ & $240 \pm 4 b$ \\
\hline Peat & $241 \pm 1 b$ & $70 \pm 4 a$ & $79 \pm 7 c$ & $81 \pm 4 c$ & $161 \pm 4 \mathrm{~b}$ \\
\hline Peat : perlite $(1: 1 \mathrm{v} / \mathrm{v})$ & $263 \pm 15 a$ & $60 \pm 5 b$ & $150 \pm 2 a$ & $199 \pm 9 a$ & $199 \pm 6 a$ \\
\hline Peat : perlite $(2: 1 \mathrm{v} / \mathrm{v})$ & $164 \pm 6 c$ & $75 \pm 2 \mathrm{a}$ & $109 \pm 5 b$ & $96 \pm 3 b$ & $130 \pm 5 c$ \\
\hline
\end{tabular}

Small Latin letters in the same column indicate significant differences between means of the same plant part (leaves + stems, and roots) according to the Tukey's HSD test $(P<0.05)$. $\mathrm{GI}_{50}$ values correspond to the sample concentration responsible for $50 \%$ inhibition of growth in a primary culture of liver cells PLP2 or in human tumor cell lines. $\mathrm{GI}_{50}$ values for ellipticine (positive control): $3 \mu \mathrm{g} \mathrm{mL}^{-1}$ (PLP2), $1.0 \mu \mathrm{gg} \mathrm{mL}^{-1}$ (MCF-7), $1.0 \mu \mathrm{g} \mathrm{mL}^{-1}$ (NCI-H460), $2.0 \mu \mathrm{g} \mathrm{mL} \mathrm{mL}^{-1}$ (HeLa) and $1.0 \mu \mathrm{g} \mathrm{mL} \mathrm{m}^{-1}$ (HepG2). 
Table 6 Antimicrobial activity of Sanguisorba minor (MIC, MFC, and MBC mg mL ${ }^{-1}$ ) extracts from leaves + stems and roots in relation to the substrate type

\begin{tabular}{|c|c|c|c|c|c|c|c|}
\hline \multicolumn{2}{|l|}{ Treatments } & \multirow[t]{2}{*}{ B. cereus } & \multirow[t]{2}{*}{ S. aureus } & L. monocytogenes & \multirow[t]{2}{*}{ E. coli } & \multirow[t]{2}{*}{ En. cloacae } & \multirow[t]{2}{*}{ S. Typhimurium } \\
\hline \multicolumn{3}{|l|}{ Leaves and stems } & & & & & \\
\hline \multirow[t]{2}{*}{ Peat } & MIC & 0.15 & 0.20 & 0.30 & 0.30 & 0.30 & 0.45 \\
\hline & MBC & 0.30 & 0.60 & 0.60 & 0.60 & 0.60 & 0.60 \\
\hline \multirow[t]{2}{*}{ Peat: perlite $(1: 1 \mathrm{v} / \mathrm{v})$} & MIC & 0.20 & 0.45 & 0.30 & 0.30 & 0.20 & 0.20 \\
\hline & MBC & 0.30 & 0.60 & 0.60 & 0.60 & 0.30 & 0.30 \\
\hline \multirow[t]{2}{*}{ Peat : perlite $(2: 1 \mathrm{v} / \mathrm{v})$} & MIC & 0.20 & 0.20 & 0.20 & 0.30 & 0.20 & 0.30 \\
\hline & $\mathrm{MBC}$ & 0.30 & 0.30 & 0.30 & 0.60 & 0.30 & 0.60 \\
\hline \multicolumn{8}{|l|}{ Roots } \\
\hline \multirow[t]{2}{*}{ Peat } & MIC & 0.10 & 0.10 & 0.10 & 0.15 & 0.10 & 0.10 \\
\hline & MBC & 0.15 & 0.15 & 0.15 & 0.30 & 0.15 & 0.15 \\
\hline \multirow[t]{2}{*}{ Peat: perlite $(1: 1 \mathrm{v} / \mathrm{v})$} & MIC & 0.10 & 0.10 & 0.10 & 0.15 & 0.10 & 0.10 \\
\hline & MBC & 0.15 & 0.15 & 0.15 & 0.30 & 0.15 & 0.15 \\
\hline \multirow{2}{*}{ Peat: perlite $(2: 1 \mathrm{v} / \mathrm{v})$} & MIC & 0.075 & 0.075 & 0.075 & 0.15 & 0.075 & 0.075 \\
\hline & MBC & 0.15 & 0.15 & 0.15 & 0.30 & 0.15 & 0.15 \\
\hline \multirow[t]{2}{*}{ Streptomycin } & MIC & 0.10 & 0.04 & 0.20 & 0.20 & 0.20 & 0.20 \\
\hline & $\mathrm{MBC}$ & 0.20 & 0.10 & 0.30 & 0.30 & 0.30 & 0.30 \\
\hline \multirow[t]{2}{*}{ Ampicillin } & MIC & 0.25 & 0.25 & 0.40 & 0.40 & 0.25 & 0.75 \\
\hline & MBC & 0.40 & 0.45 & 0.50 & 0.50 & 0.50 & 1.20 \\
\hline \multicolumn{2}{|l|}{ Treatments } & A. fumigatus & A. ochraceus & A. niger & P. funiculosum & P. ochrochloron & P. v. cyclopium \\
\hline \multicolumn{8}{|l|}{ Leaves and stems } \\
\hline \multirow[t]{2}{*}{ Peat } & MIC & 0.60 & 0.15 & 0.45 & 0.45 & 0.60 & 0.90 \\
\hline & MFC & 0.90 & 0.30 & 0.90 & 0.90 & 1.20 & 1.20 \\
\hline \multirow[t]{2}{*}{ Peat: perlite $(1: 1 \mathrm{v} / \mathrm{v})$} & MIC & 0.30 & 0.10 & 0.45 & 0.30 & 0.30 & 0.30 \\
\hline & MFC & 0.60 & 0.15 & 0.60 & 0.60 & 0.60 & 0.60 \\
\hline \multirow{2}{*}{ Peat : perlite $(2: 1 \mathrm{v} / \mathrm{v})$} & MIC & 0.30 & 0.10 & 0.30 & 0.30 & 0.45 & 0.60 \\
\hline & MFC & 0.60 & 0.15 & 0.60 & 0.60 & 0.90 & 1.20 \\
\hline \multicolumn{8}{|l|}{ Roots } \\
\hline \multirow[t]{2}{*}{ Peat } & MIC & 0.15 & 0.05 & 0.30 & 0.15 & 0.10 & 0.15 \\
\hline & MFC & 0.30 & 0.075 & 0.60 & 0.30 & 0.30 & 0.30 \\
\hline \multirow[t]{2}{*}{ Peat : perlite $(1: 1 \mathrm{v} / \mathrm{v})$} & MIC & 0.30 & 0.075 & 0.15 & 0.10 & 0.15 & 0.15 \\
\hline & MFC & 0.60 & 0.15 & 0.30 & 0.30 & 0.30 & 0.30 \\
\hline Peat: perlite $(2: 1 \mathrm{v} / \mathrm{v})$ & MIC & 0.15 & 0.075 & 0.45 & 0.30 & 0.15 & 0.15 \\
\hline & MFC & 0.30 & 0.15 & 0.60 & 0.60 & 0.30 & 0.30 \\
\hline Ketoconazole & MIC & 0.25 & 0.20 & 0.20 & 0.20 & 2.50 & 0.20 \\
\hline & MFC & 0.50 & 0.50 & 0.50 & 0.50 & 3.50 & 0.30 \\
\hline Bifonazole & MIC & 0.15 & 0.10 & 0.15 & 0.20 & 0.20 & 0.10 \\
\hline & MFC & 0.20 & 0.20 & 0.20 & 0.25 & 0.25 & 0.20 \\
\hline
\end{tabular}

MIC: minimum inhibitory concentration, MBC: minimum bactericidal concentration, MFC: minimum fungicidal concentration. Streptomycin and ampicillin, and ketoconazole and bifonazole were used as positive controls for antibacterial and antifungal activity, respectively.

being the case of $S$. aureus where streptomycin showed the highest activity. Moreover, root extracts exhibited the ability to inhibit the growth of B. cereus, En. cloacae, L. monocytogenes, $S$. aureus, and $S$. typhimurium, at concentrations of 0.075 $\mathrm{mg} \mathrm{mL}^{-1}$. Regarding the effect of the tested substrates, root extracts from plants grown on the peat: perlite $(2: 1 \mathrm{v} / \mathrm{v})$ substrate had lower MIC values than the other substrates, except for the cases of $S$. aureus where streptomycin had the lowest values $\left(0.04 \mu \mathrm{g} \mathrm{mL}^{-1}\right)$, whereas the lowest $\mathrm{MBC}$ values were observed for the peat and peat: perlite $(2: 1 \mathrm{v} / \mathrm{v})$ substrates. Gawron-Gzella et $a l^{40}$ reported that extracts from $S$. officinalis exhibited antimicrobial activity against the strains of various bacteria (Staphylococcus aureus, Staphylococcus epidermidis, Micrococcus luteus, Bacillus subtilis, Escherichia coli, Klebsiella pneumoniae and Pseudomonas aeruginosa) with MIC values ranging between 0.07 and $2.50 \mathrm{mg} \mathrm{mL}^{-1}$. In another recent study, Ginovyan et al. ${ }^{41}$ also reported that the extracts from
S. officinalis revealed antibacterial activity against Pseudomonas aeruginosa at the concentration of $64 \mu \mathrm{g} \mathrm{mL} \mathrm{m}^{-1}$. Antibacterial activity of $S$. minor had been also described in the study of Talibi et $a .^{42}$ who tested the efficacy of extracts from stems and leaves against Clavibacter michiganensis subsp. michiganensis.

Regarding the antifungal activity of $S$. minor extracts, six fungi were assessed, namely Aspergillus fumigatus, A. Niger, A. ochraceus, P. funiculosum, P. ochrochloron, and P. verrucosum var. cyclopium (Table 6). All the extracts revealed antifungal activity, with roots extracts showing the lowest MIC and MFC values, ranging between 0.05 and $0.45 \mathrm{mg} \mathrm{mL}^{-1}$ and between 0.075 and $0.60 \mathrm{mg} \mathrm{mL}{ }^{-1}$, respectively. Ketoconazole and bifonazole were applied as positive controls, and only bifonazole showed a similar or better antifungal activity than the tested root extracts, except for the case of A. ochraceus where root extracts from peat grown plants had the lowest MIC and MFC values. In addition, $A$. Niger and $P$. ochrochloron were the fungi 
with the lowest sensitivity to the extracts. Regarding the effect of the tested substrates, antimicrobial activity of plant extracts showed a varied response depending on the assayed fungi. Similarly, Gatto et al. ${ }^{37}$ observed that extracts from $S$. minor aerial parts revealed antifungal capacity against to A. niger, Penicillium digitatum, and P. italicum, while Askarne et al. ${ }^{43}$ reported a significant inhibition activity of extracts from leaves and stems against P. italicum. In a recent study, GawronGzella $^{40}$ also suggested that extracts from $S$. officinalis showed antifungal activity against Candida albicans.

\section{Conclusions}

The present work was carried out in order to evaluate the effects of substrates on the growth of Sanguisorba minor plants, and on the chemical composition and antitumor and antimicrobial capacity of extracts from roots and aerial parts of the plants. Our results revealed that the higher chlorophyll content and dry weight of roots, stems and leaves were recorded in the peat treatment. Overall, the growing conditions affected the nutritional value, chemical composition, and antitumor and antimicrobial properties of S. minor. Moreover, extracts from the roots had a higher antimicrobial and antitumor capacity against the tested cancer lines in comparison to extracts from the leaves and stems, except for the case of HepG2 cancer lines and PLP2 non-tumor cell lines, where extracts from the leaves and stems were more efficient and less cytotoxic, respectively. The higher antimicrobial and antitumor activity of plant roots could be probably attributed to the higher phenolic compound content and the different composition of phenolic compounds, although further studies are needed in order to investigate bioactivities of these compounds. The present work provides valuable results regarding the effects of growing conditions on the growth and bioactive properties of $S$. minor. Considering the importance of the species in traditional medicine, it could be assumed that the increase of the bioactive compound content through commercial growing conditions, especially phenolic compounds, would also enhance the functionality of the species. Moreover, although the species is commonly found in the Mediterranean region, it is underexploited yet and its tissues could be a potential source of natural bioactive compounds with further use in pharmaceutical and medicinal applications.

\section{Conflicts of interest}

All authors declare that they do not have any conflict of interest for publishing this research work.

\section{Acknowledgements}

The authors are grateful to the Foundation for Science and Technology (FCT, Portugal) and FEDER under Programme PT2020 for financial support to CIMO (UID/AGR/00690/2013),
A. Fernandes grant (SFRH/BPD/114753/2016), and L. Barros contract. The authors are also grateful to FEDER-Interreg España-Portugal programme for financial support through the project 0377_Iberphenol_6_E.

\section{References}

1 S. M. Andrabi, W. Rehman, Z. A. Reshi, A. R. Naqshi and G. H. Aijaz, Sanguisorba minor Scop. (Rosaceae), a new addition to the Indian flora, Taiwania, 2012, 57, 410-412.

2 A. Karkanis, E. Vellios, $T$ Thomaidis, D. Bilalis, A. Efthimiadou and I. Travlos, Phytochemistry and biological properties of burnet weed (Sanguisorba spp.): A review, Not. Sci. Biol., 2014, 6, 395-398.

3 S. Tausch, M. Leipold, P. Poschlod and C. Reisch, Molecular markers provide evidence for a broad-fronted recolonisation of the widespread calcareous grassland species Sanguisorba minor from southern and cryptic northern refugia, Plant Biol., 2017, 19, 562-570.

4 P. M. Guarrera and V. Savo, Wild food plants used in traditional vegetable mixtures in Italy, J. Ethnopharmacol., 2016, 185, 202-234.

5 A. Romojaro, M. Serrano and M. T. Pretel, Wild edible plants (WEP) as antioxidant supplements for oils and juices, Acta Hortic., 2018, 1194, 1039-1044.

6 A. Elgersma, K. Søegaard and S. K. Jensen, Interrelations between herbage yield, $\alpha$-tocopherol, $\beta$-carotene, lutein, protein, and fiber in non-leguminous forbs, forage legumes, and a grass-clover mixture as affected by harvest date, J. Agric. Food Chem., 2015, 63, 406-414.

7 Z. Zhao, X. He, Q. Zhang, X. Wei and L. Huang, Traditional uses, chemical constituents and biological activities of plants from the genus Sanguisorba L, Am. J. Chin. Med., 2017, 45, 199-224.

8 N. A. Ayoub, Unique phenolic carboxylic acids from Sanguisorba minor, Phytochemistry, 2003, 63, 433-436.

9 A. Biernasiuk, M. Wozniak and A. Bogucka-kocka, Determination of free and bounded phenolic acids in the rhizomes and herb of Sanguisorba officinalis L, Curr. Issues Pharm. Med. Sci., 2015, 28, 254-256.

10 S. Zhang, X. Liu, Z. Zhang, L. He, Z. Wang and G. Wang, Isolation and identification of the phenolic compounds from the roots of Sanguisorba officinalis L. and their antioxidant activities, Molecules, 2012, 17, 13917-13922.

11 A. Ferreira, C. Proença, M. L. M. Serralheiro and M. E. M. Araújo, The in vitro screening for acetylcholinesterase inhibition and antioxidant activity of medicinal plants from Portugal, J. Ethnopharmacol., 2006, 108, 31-37.

12 M. Cuccioloni, L. Bonfili, M. Mozzicafreddo, V. Cecarini, A. M. Eleuteri and M. Angeletti, Sanguisorba minor extract suppresses plasmin-mediated mechanisms of cancer cell migration, Biochim. Biophys. Acta, Gen. Subj., 2012, 1820, 1027-1034.

13 A. Zhu, H. Zhou, J. Xia, H. Jin, K. Wang, J. Yan, J. Zuo, X. Zhu and T. Shan, Ziyuglycoside II-induced apoptosis in 
human gastric carcinoma BGC-823 cells by regulating Bax/ Bcl-2 expression and activating caspase-3 pathway, Braz. J. Med. Biol. Res., 2013, 46, 670-675.

14 X. Zhu, K. Wang, Y. Yao, K. Zhang, F. Zhou and L. Zhu, Triggering p53 activation is essential in ziyuglycoside I-induced human retinoblastoma WERI-Rb-1 cell apoptosis, J. Biochem. Mol. Toxicol., 2018, 32, 1-7.

15 M. P. Liu, M. Liao, C. Dai, J. F. Chen, C. J. Yang, M. Liu, Z. G. Chen and M. C. Yao, Sanguisorba officinalis L synergistically enhanced 5-fluorouracil cytotoxicity in colorectal cancer cells by promoting a reactive oxygen speciesmediated, mitochondria-caspase-dependent apoptotic pathway, Sci. Rep., 2016, 6, 34245.

16 M. Liu, W. Li, C. Dai, C. W. Kei Lam, Z. Li, J. Chen, Z. Chen, W. Zhang and M. Yao, Aqueous extract of Sanguisorba officinalis blocks the Wnt/ $\beta$-catenin signaling pathway in colorectal cancer cells, RSC Adv., 2018, 8, 10197-10206.

17 S. Nam, K. Lkhagvasuren, H. W. Seo and J. Kim, Antiangiogenic effects of ziyuglycoside II, a major active compound of Sanguisorba officinalis L, Phyther. Res., 2017, 31, 1449-1456.

18 X. D. Su, R. H. Guo, H. X. Li, J. Y. Ma, Y. R. Kim, Y. H. Kim and S. Y. Yang, Anti-allergic inflammatory components from Sanguisorba officinalis L, Bioorg. Med. Chem. Lett., 2018, 28, 2210-2216.

19 AOAC, in Official methods of analysis of AOAC International, Official Methods of Analysis of $A O A C$ International, ed. W. Horwitz and G. Latimer, AOAC International, Gaithersburg, MD, 20th edn, 2016.

20 L. Barros, E. Pereira, R. C. Calhelha, M. Dueñas, A. M. Carvalho, C. Santos-Buelga and I. C. F. R. Ferreira, Bioactivity and chemical characterization in hydrophilic and lipophilic compounds of Chenopodium ambrosioides L, J. Funct. Foods, 2013, 5, 1732-1740.

21 L. Barros, C. Pereira and I. C. F. R. Ferreira, Optimized analysis of organic acids in edible mushrooms from Portugal by Ultra-Fast Liquid Chromatography and Photodiode Array Detection, Food Anal. Methods, 2013, 6, 309-316.

22 S. M. F. Bessada, J. C. M. Barreira, L. Barros, I. C. F. R. Ferreira and M. B. P. P. Oliveira, Phenolic profile and antioxidant activity of Coleostephus myconis (L.) Rchb.f.: An underexploited and highly disseminated species, Ind. Crops Prod., 2016, 89, 45-51.

23 R. M. V. Abreu, I. C. F. R. Ferreira, R. C. Calhelha, R. T. Lima, M. H. Vasconcelos, F. Adega, R. Chaves and M.-J. R. P. Queiroz, Anti-hepatocellular carcinoma activity using human HepG2 cells and hepatotoxicity of 6-substituted methyl 3-aminothieno[3,2-b]pyridine-2-carboxylate derivatives: In vitro evaluation, cell cycle analysis and QSAR studies, Eur. J. Med. Chem., 2011, 46, 5800-5806.

24 S. Petropoulos, Â. Fernandes, L. Barros, A. Ciric, M. Sokovic and I. C. F. R. Ferreira, The chemical composition, nutritional value and antimicrobial properties of Abelmoschus esculentus seeds, Food Funct., 2017, 8, 4733-4743.

25 A. Baghbani-Arani, S. A. M. Modarres-Sanavy, M. Mashhadi-Akbar-Boojar and A. Mokhtassi-Bidgoli,
Towards improving the agronomic performance, chlorophyll fluorescence parameters and pigments in fenugreek using zeolite and vermicompost under deficit water stress, Ind. Crops Prod., 2017, 109, 346-357.

26 H. Mohammadi, M. Esmailpour, S. Ghorbi and M. Hatami, Physiological and biochemical changes in Matricaria chamomilla induced by Pseudomonas fluorescens and water deficit stress, Acta Agric. Slov., 2018, 111, 63-72.

27 A. C. Karkanis and S. A. Petropoulos, Physiological and growth responses of several genotypes of common purslane (Portulaca oleracea L.) under Mediterranean semi-arid conditions, Not. Bot. Horti Agrobot. Cluj-Napoca, 2017, 45, 569-575.

28 L. Zhang, S. R. Koyyalamudi, S. C. Jeong, N. Reddy, P. T. Smith, R. Ananthan and T. Longvah, Antioxidant and immunomodulatory activities of polysaccharides from the roots of Sanguisorba officinalis, Int. J. Biol. Macromol., 2012, 51, 1057-1062.

29 A. Elgersma, K. Søegaard and S. K. Jensen, Fatty acids, $\alpha$-tocopherol, $\beta$-carotene, and lutein contents in forage legumes, forbs, and a grass-clover mixture, J. Agric. Food Chem., 2013, 61, 11913-11920.

30 J. Viano, V. Masotti and E. M. Gaydou, Nutritional value of Mediterranean sheep's burnet (Sanguisorba minor ssp. muricata), J. Agric. Food Chem., 1999, 47, 4645-4648.

31 J. L. Guil, M. E. Torija, J. J. Giménez and I. Rodriguez, Identification of fatty acids in edible wild plants by gas chromatography, J. Chromatogr. A, 1996, 719, 229-235.

32 Y. Murai and T. Iwashina, Phenolic compounds from Sanguisorba obtusa endemic to Japan, Bull. Natl. Sci. Mus., Ser. B, 2016, 42, 143-147.

33 M. Carocho, L. Barros, A. Bento, C. Santos-buelga, P. Morales and I. C. F. R. Ferreira, Castanea sativa Mill. flowers amongst the most powerful antioxidant matrices: A phytochemical approach in decoctions and infusions, BioMed Res. Int., 2014, 1-7.

34 M. Sanz, E. Cadahía, E. Esteruelas, M. ÁM, B. d. Simón, T. Hernández and I. Estrella, Phenolic compounds in chestnut (Castanea sativa Mill.) heartwood. Effect of toasting at cooperage, J. Agric. Food Chem., 2010, 58, 9631-9640.

35 A. Martins, L. Barros, A. M. Carvalho, C. Santos-Buelga, I. P. Fernandes, F. Barreiro and I. C. F. R. Ferreira, Phenolic extracts of Rubus ulmifolius Schott flowers: characterization, microencapsulation and incorporation into yogurts as nutraceutical sources, Food Funct., 2014, 5, 1091-1100.

36 C. Pereira, L. Barros, M. J. Alves, L. Pereira, C. SantosBuelga and I. C. F. R. Ferreira, Phenolic profile and antimicrobial activity of different dietary supplements based on Cochlospermum angolensis Welw, Ind. Crops Prod., 2015, 74, 412-416.

37 M. A. Gatto, A. Ippolito, V. Linsalata, N. A. Cascarano, F. Nigro, S. Vanadia and D. D. Venere, Activity of extracts from wild edible herbs against postharvest fungal diseases of fruit and vegetables, Postharvest Biol. Technol., 2011, 61, 72-82.

38 M. Kaplan, A. Kamalak, A. A. Kasra and İ. Güven, Effect of maturity stages on potential nutritive value, methane pro- 
duction and condensed tannin content of Sanguisorba minor hay, Kafkas Univ. Vet. Fak. Derg., 2014, 20, 445-449.

39 J.-A. Shin, J.-S. Kim, K.-H. Kwon, J.-S. Nam, J.-Y. Jung, N.-P. Cho and S.-D. Cho, Apoptotic effect of hot water extract of Sanguisorba officinalis L. in human oral cancer cells, Oncol. Lett., 2012, 4, 489-494.

40 A. Gawron-Gzella, E. Witkowska-Banaszczak, W. Bylka, M. Dudek-Makuch, A. Odwrot and N. Skrodzka, Chemical composition, antioxidant and antimicrobial activities of Sanguisorba officinalis L. extracts, Pharm. Chem. J., 2016, 50, 244-249.

41 M. Ginovyan, M. Petrosyan and A. Trchounian, Antimicrobial activity of some plant materials used in
Armenian traditional medicine. BMC Complement Altern Med., BMC Complementary Altern. Med., 2017, 17, 1-9.

42 I. Talibi, N. Amkraz, L. Askarne, F. Msanda, B. Saadi, E. Boudyach, H. Boubaker and B. Bouizgarne, Ait Ben Aoumar A. Antibacterial activity of moroccan plants extracts against Clavibacter michiganensis subsp. michiganensis, the causal agent of tomatoes' bacterial canker, J. Med. Plants Res., 2011, 5, 4332-4338.

43 L. Askarne, I. Talibi, H. Boubaker, E. H. Boudyach, F. Msanda, B. Saadi, M. A. Serghini and A. Ait Ben Aoumar, In vitro and in vivo antifungal activity of several Moroccan plants against Penicillium italicum, the causal agent of citrus blue mold, Crop Prot., 2012, 40, 53-58. 